\title{
Socio-Economic Characteristics and Problems Faced by Apple Cultivators Under with Drip and without Drip Irrigation System
}

\author{
Sreelekha Kudamala", Subhash Sharma and Amit Guleria
}

Dr. Yashwant Singh Parmar University of Horticulture and Forestry, Agriculture, Department of Social Sciences, Nauni-173230, Solan, Himachal Pradesh, India

"Corresponding author: sreelekhahorti@gmail.com

\begin{abstract}
Apple is the main fruit crop of Himachal Pradesh and is grown in nine out of the twelve districts. It contributes to 40 per cent of the fruit growing areas in Himachal Pradesh. A sample of 60 farmers cultivating apple was selected using multistage simple random sampling. Out of 60 farmers 30 farmers are with drip irrigation and 30 farmers are without drip irrigation. Literacy situation revealed that 93.37 per cent family members were literates with a literacy index of 3.37 in case of with drip irrigation farms. In case of without drip irrigation farms, 91.61 per cent family members were found literates with a literacy index of 3.05. Average size of land holding was 1.34 and 1.38 ha on with drip and without drip irrigation farms, respectively which is low due to more area under apple. Area under apple has been found to be 64.35 per cent out of total cultivated land on with drip irrigation farms and in case of without drip irrigation farms it was 67.09 per cent out of total cultivated land. The main problems of farmers with drip irrigation were clogging of emitters (83.33\%), difficulty in inter cropping and high cost of spare parts $(66.67 \%)$ each and irregular electric supply and spare parts not available at village $(63.33 \%)$ each. The main problems of farmers without drip irrigation were high cost of establishment (86.67\%), lack of knowledge on subsidy (73.33\%) and lack of technical knowledge (70.00\%).
\end{abstract}

Highlights

(0 The main problems of farmers with drip irrigation were clogging of emitters, difficulty in inter cropping and high cost of spare parts.

Keywords: Apple, drip irrigation, socio-economic characteristics, problems

India is currently producing about 238 million tonnes of horticulture produce and horticulture production has surpassed the food production in the country. It has proven beyond doubt that productivity of horticulture crops is much higher compared to productivity of food grains. Horticulture sector has emerged as a driving force for agricultural development in India. The sector is most profitable venture for all farming activities, as it provides ample employment opportunities and scope to raise income of the farming community in the country. Realizing these potentials, the government of India started putting greater thrust for the development of horticultural sector after sixties in order to exploit the country's vast potential and to generate the much needed value addition.

Apple has been found to be growing over an area of 2,77,300 hectares with a production of $22,41,700 \mathrm{MT}$ and productivity of $8.1 \mathrm{MT} / \mathrm{ha}$ in the year 2016-2017 in India (Anonymous, 2017). Apple is the main fruit crop of Himachal Pradesh and is grown in nine out of the twelve districts. It contributes to 40 per cent of the fruit growing areas in Himachal Pradesh. The apple accounted for $1,11,896$ hectares with a production of 4,68,134 MT and a productivity of $4.18 \mathrm{MT} / \mathrm{ha}$ in the year 2016-17 in Himachal Pradesh (Anonymous 2017). Kinnaur and Shimla are the main apple producing 
districts of Himachal Pradesh. Many farm families are depending on apple cultivation. The cultivation of apple in Himachal is more remunerative than the other field crops. Apple determines the income and purchasing power of the farmer and has a positive impact in terms of people's living standard in the state. Besides apple growers, the process of picking, grading, packing and transportation of apple provides employment to many persons.

The ability to repeatedly produce high quality apples of the optimum economic size is critical to grower's economic success. The two most important biological and management factors affecting fruit size are crop load and water stress. To repeatedly produce consistent crops of large fruit size requires precise control over crop load and tree water status. Irrigation is essential to prevent water stress in dry summers and small fruit size. In hilly region where surface irrigation is not suitable due to undulating topography, shallow and light textured soils with low water holding capacity and availability of meager resources, drip irrigation is one of the latest methods of irrigation which has good potential of increasing yield with high water use efficiency. Drip irrigation saves water considerably. This study has been carried out in order to find out the problems faced by apple cultivators under with and without drip irrigation system with following specific objectives: (i) Socio-economic characteristics of apple growers (ii) Problems faced by apple cultivators under with drip and without drip irrigation system in the study area.

\section{MATERIAL AND METHODS}

The present study was undertaken during 2018 in the Shimla district of Himachal Pradesh. Shimla district of Himachal Pradesh was selected purposively because of its significant contribution with respect to area and production of apple and drip irrigation is also more prominent in apple in the state, simultaneously providing fruitful employment to the families involved in apple cultivation.

Multistage random sampling was adopted to select the ultimate sample of the respondents i.e. the fruit growers. Shimla district consists of 11 blocks and drip irrigation is mostly used in 5 blocks. At the first stage 2 blocks namely Theog and Kotkhai out of 5 blocks were selected randomly. At the second stage two villages from each block were selected randomly. At the third stage a sample of 15 apple growers from each selected village were selected randomly. Thus the total sample consisted of 60 respondents out of which 30 respondents were with drip irrigation and 30 respondents were without drip irrigation.

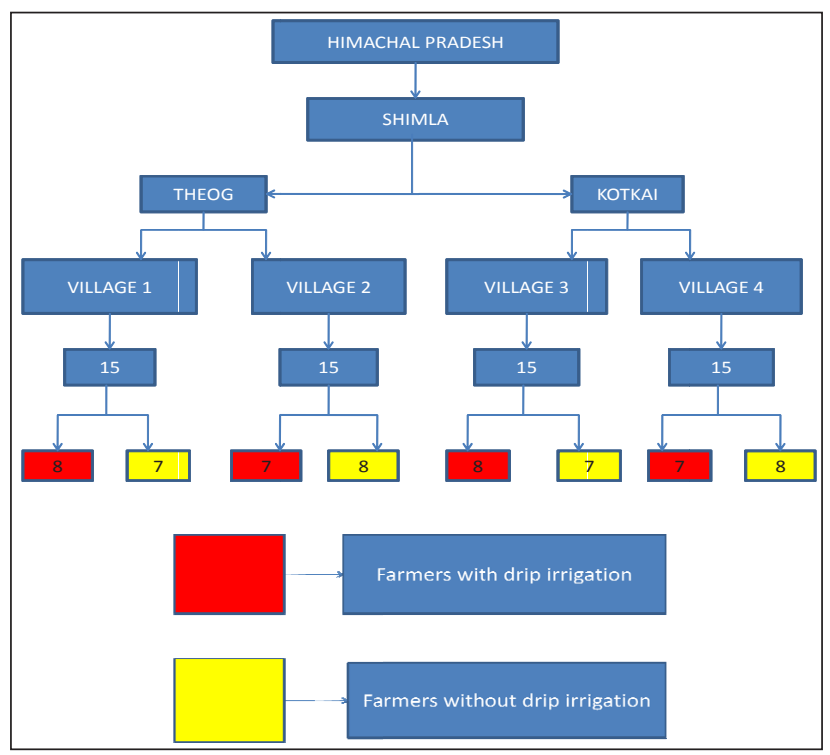

Fig. 1: Pictorial representation of selection of sampled households

\section{Livestock Inventory}

The adult cattle units (ACU) were worked out by using the equivalent as follows:

(i) One buffalo equivalent to $1.3 \mathrm{ACU}$.

(ii) One cow or bullock equivalent to 1 ACU.

(iii) One number of the young stock equivalent to $0.75 \mathrm{ACU}$.

(iv) One calf equivalent to $0.30 \mathrm{ACU}$.

\section{Compound growth rate (CGR)}

The compound growth rates for different variables were computed by fitting the exponential function to area, production and productivity of total fruits and apple of Himachal Pradesh for the period 196566 to 2016-17. The ordinary least square method was used to fit the exponential function of the following form and it was converted into log linear function with the help of logarithmatic transformation as under:

$$
\begin{aligned}
& Y=a e^{b t} \\
& \operatorname{Ln} \mathrm{Y}=\operatorname{Ln} \mathrm{a}+\mathrm{bt} .
\end{aligned}
$$


where,

$Y=$ Dependant variable (area, production and productivity)

$t=$ Independent variable (time in a year).

Compound growth rate (CGR) was calculated by using the following formula:

$$
\mathrm{CGR}=\mathrm{b} \times 100
$$

Standard error (SE) of CGR was calculated by using the following formula:

$$
\mathrm{SE} \text { of } \mathrm{CGR}=100 \times \mathrm{SE}(\mathrm{b})
$$

For significance testing $\mathrm{t}$ value was calculated using formula:

$$
t=\frac{C G R}{S E(C G R)}
$$

\section{Chi-square test}

To test whether there is any significant difference among the responses of with and without drip irrigation farmers regarding the problems faced in apple cultivation under drip irrigation system.

The detail of approximate Chi-square test $\left(\chi^{2}\right)$ is given as under:

$$
\sum_{i=1}^{L} \sum_{i=1}^{K} \frac{(O-E)^{2}}{E} \sim(L-1)(K-1) d . f .
$$

where,

$\mathrm{O}=$ Observed values

$\mathrm{E}=$ Expected values

$\mathrm{K}=$ Number of problems

$\mathrm{L}=$ Number of farm groups

\section{RESULTS AND DISCUSSION}

\section{Socio-economic characteristics of apple growers}

An attempt has been made in this section to find out the important socio-economic characteristics of the sampled households for these factors have relevance in determining not only the size and quality of labour force and the resources available to different categories of households but also the nature of economic activities that can be taken up to improve their socio-economic well-being. The socioeconomic characteristics of sampled households in the study area have been presented in Table 1.

Table 1: Farm specific characteristics of sampled households of with drip and without drip irrigation farms

\begin{tabular}{lcc}
\hline Particulars & With Drip & $\begin{array}{c}\text { Without } \\
\text { Drip }\end{array}$ \\
\hline Number of Families & 30.00 & 30.00 \\
Joint Family (\%) & $13.00(43.33)$ & $11.00(36.67)$ \\
Nuclear Family (\%) & $17.00(56.67)$ & $19.00(63.33)$ \\
Average family size & 5.63 & 4.90 \\
Male & $2.92(51.88)$ & $2.57(52.04)$ \\
Female & $2.71(48.12)$ & $2.39(47.96)$ \\
Sex ratio & 931 & 922 \\
Literacy rate (\%) & 93.37 & 91.61 \\
Literacy index & 3.37 & 3.05 \\
Service (\%) & 10.49 & 12.50 \\
Business (\%) & 4.20 & 8.04 \\
Agriculture (\%) & 85.31 & 79.46 \\
Average No. of workers & $4.76(84.62)$ & $3.73(76.19)$ \\
Average No. of dependents & $0.87(15.38)$ & $1.17(23.81)$ \\
(<14 yrs \& $>65$ yrs) & & \\
Dependency Ratio with respect & $1: 0.15$ & $1: 0.24$ \\
to family size & & \\
Average area under apple (ha) & $0.97(64.35)$ & $1.02(67.09)$ \\
Total cultivated area (ha) & 1.24 & 1.28 \\
Total land holding (ha) & 1.34 & 1.38 \\
Cropping intensity (\%) & 121.82 & 119.62 \\
Adult cattle units (ACU) & 3.75 & 3.27 \\
\hline
\end{tabular}

Figures in parentheses are percentage.

Nuclear type of families has been found to be more than 50 per cent on both with drip and without drip irrigation farms in the sampled households. The average family size was 5.63 persons comprising of 51.88 per cent males and 48.12 per cent females in with drip irrigation farms whereas, in case of without drip irrigation farms, it was 4.90 with 52.04 per cent males and 47.96 per cent females. The number of females per thousand of males has been worked out to be 931 on with drip irrigation farms, whereas, it has been worked out to be 922 on without drip irrigation farms. The literacy rate and literacy index of the study area was 93.37 per cent and 3.37 on with drip and 91.61 per cent and 3.05 on without drip irrigation farms, respectively. 
D Kudamala

Table 2: Compound growth rate of total fruits and apple in Himachal Pradesh (1965-66 to 2016-17)

\begin{tabular}{ccccccc}
\hline \multirow{2}{*}{ Particulars } & \multicolumn{3}{c}{ Total fruits } & \multicolumn{3}{c}{ Apple } \\
\cline { 2 - 7 } & Area & Production & Productivity & Area & Production & Productivity \\
\hline Coefficient (b) & 0.040 & 0.045 & 0.005 & 0.036 & 0.048 & -0.039 \\
CAGR (\%) & $4.00^{* *}$ & $4.50^{* *}$ & 0.50 & $3.60^{* *}$ & $4.80^{* *}$ & $-3.90^{* *}$ \\
\hline
\end{tabular}

**Significant at 5 per cent level of significance.

This indicated that literacy rate in the study area was higher, but the quality of education was poor as indicated by low literacy index, so there is a need to improve the literacy status.

On with drip irrigation farms the average size of the family was 5.63 members per family out of which 84.62 per cent were active workers and 15.38 per cent were dependents, whereas, in case of without drip irrigation farms it was 4.90 out of which 76.19 per cent were active workers and 23.81 per cent were dependents. It is noted that agriculture has been the main occupation as 85.31 per cent and 79.46 per cent of work force practice farming on with drip and without drip irrigation farms respectively. On an average 10.49 per cent workers population were engaged in public/private services as secondary occupation and 4.20 per cent population engaged in business on with drip irrigation farms. Similarly, in case of without drip irrigation farms, 12.50 and 8.04 per cent worker's population have been engaged in services and business respectively. Dependency ratio with respect to family size has been found to be 1:0.15 and 1:0.24 on with drip and without drip irrigation farms, respectively. Average size of land holding per sampled respondents has been found to be 1.34 hectare, out of which 1.24 hectare was cultivated area on with drip irrigation farms. On without drip irrigation farms average size of

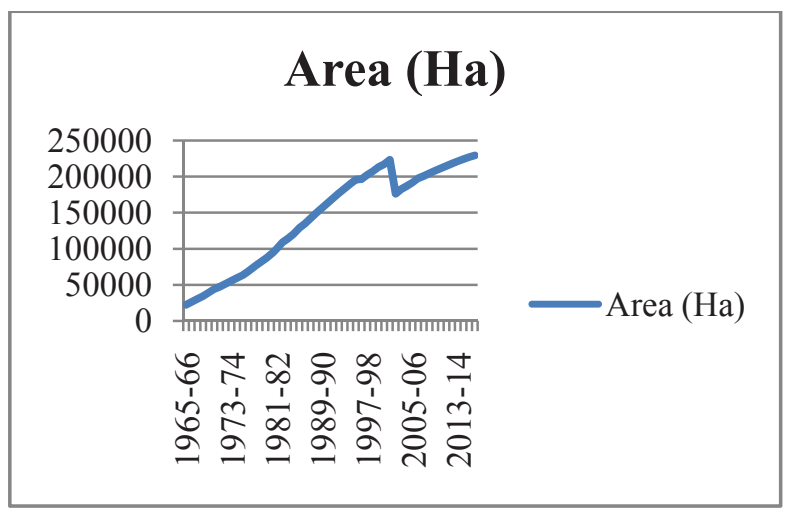

Fig. 2: Area of total fruits in Himachal Pradesh land holding was 1.38 hectare, out of which 1.28 hectare was cultivated area. The cropping intensity of the study area was 121.82 per cent on with drip irrigation farms, whereas, in case of without drip irrigation farms it was 119.62 per cent. Lower cropping intensity was because of the area under fruit crop which accounted for more than 50 per cent of gross cropped area. Adult cattle units has been found to be 3.75 and 3.27 on with drip and without drip irrigation farms respectively.

Area under apple has been found to be 64.35 per cent out of total cultivated land on with drip irrigation farms and in case of without drip irrigation farms it was 67.09 per cent out of total cultivated land.

The level of growth in output is jointly determined by the growth in area and production. The purpose of this analysis is to examine the performance of total fruits and apple cultivation in Himachal Pradesh and to see if there have been any noticeable changes from 1965-66 to 2016-17. This helped in finding out the underlying factors responsible for such performance and thereby permits a broad judgment about the overall production possibilities in times to come.

The compound growth rate of total fruits and apple in Himachal Pradesh were given in Table 2. Area, production and productivity of total fruits and apple have been presented in Fig. 2 to 7. The data

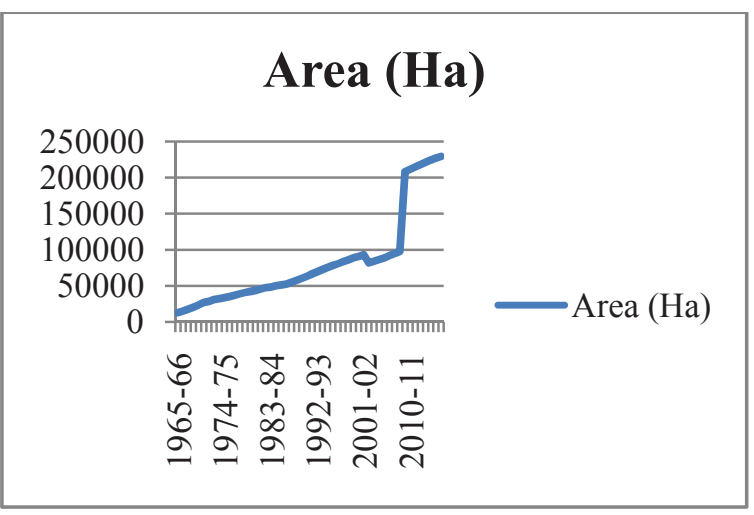

Fig. 3: Area of apple in Himachal Pradesh 


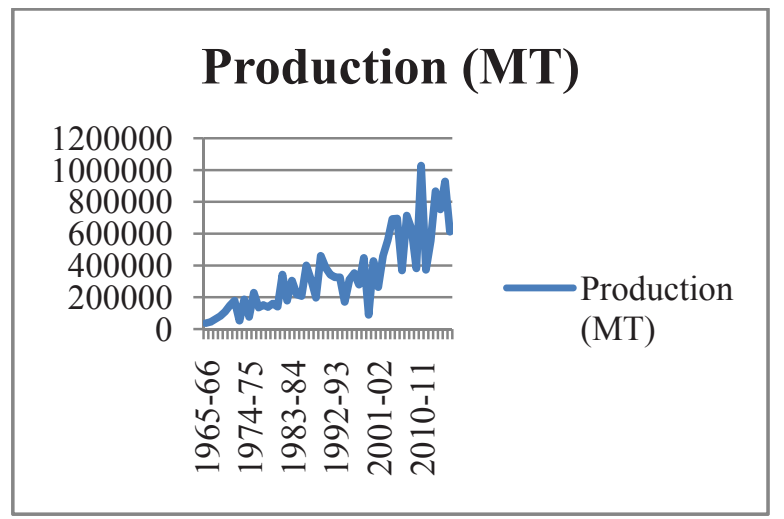

Fig. 4: Production of total fruits in Himachal Pradesh

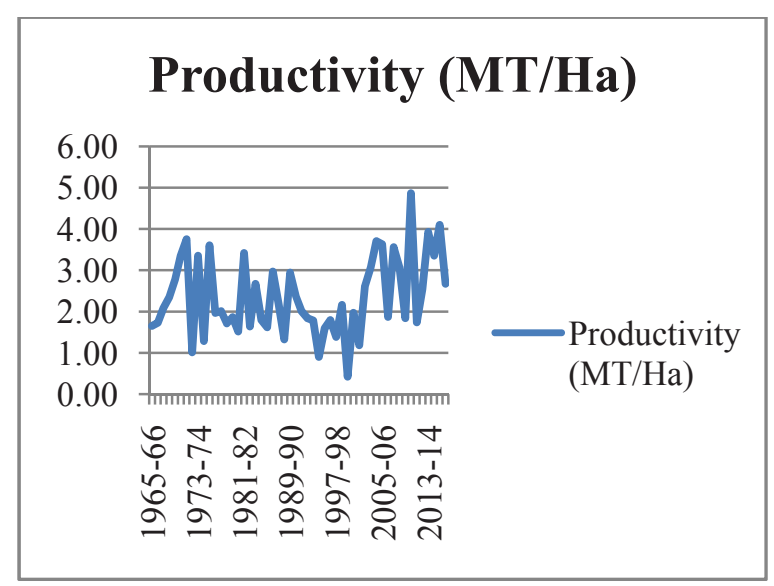

Fig. 6: Productivity of total fruits in Himachal Pradesh

revealed that the compound annual growth rate of area, production and productivity of total fruits in Himachal Pradesh was 4.00, 4.50 and 0.50 per cent, respectively during 1965-66 to 2016-17. While in case of apple it was observed that 3.60, 4.80 and -3.90 per cent in area, production and productivity, respectively.

Area and production was increasing significantly at 5 per cent level in both total fruits and apple in Himachal Pradesh. Productivity was not increasing significantly in case of total fruits and in apple it was decreasing in Himachal Pradesh.

The main problems of farmers with drip irrigation were clogging of emitters $(83.33 \%)$, difficulty in inter cropping and high cost of spare parts $(66.67 \%)$ each, irregular electric supply and spare parts not available at village $(63.33 \%)$ each, delay in sanction of loan or subsidy $(60.00 \%)$, high cost of establishment, lack of technical knowledge, material transport facilities, damage caused by animals/ rodents $(53.33 \%)$ each, complicated procedure for

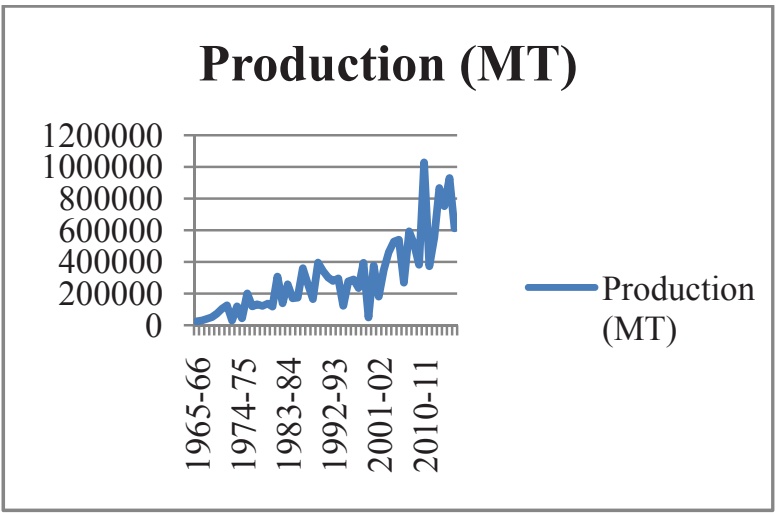

Fig. 5: Production of apple in Himachal Pradesh

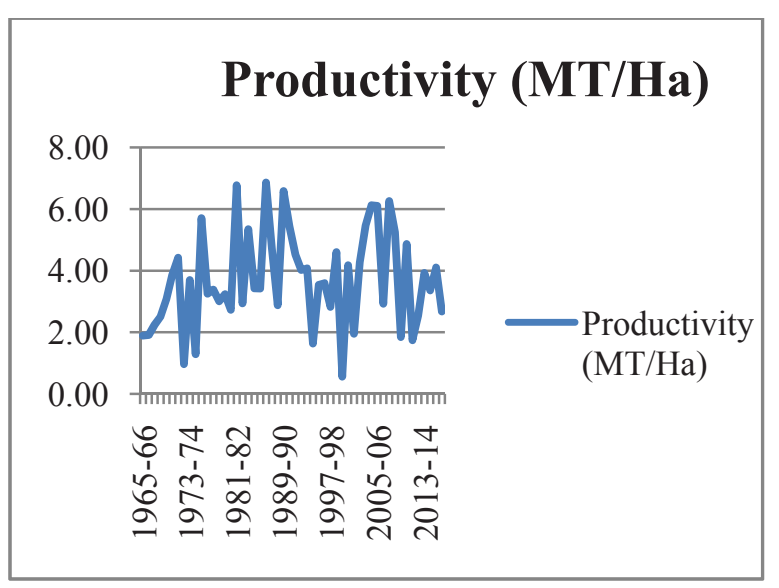

Fig. 7: Productivity of apple in Himachal Pradesh

loan/subsidy, lack of guidance, irregular services $(46.67 \%)$ each, irregular water supply $(43.33 \%)$, lack of financial support $(23.33 \%)$ and lack of knowledge on subsidy (6.67\%). The main problems of farmers without drip irrigation were high cost of establishment (86.67), lack of knowledge on subsidy (73.33), lack of technical knowledge (70.00\%), lack of financial support and lack of guidance (60.00) each, complicated procedure for loan/subsidy (53.33\%), irregular electric supply $(36.67 \%)$, irregular water supply, high cost of spare parts, difficulty in inter cropping $(33.33 \%)$ each, material transport facilities, spare parts not available at village $(26.67 \%)$, irregular services $(20.00 \%)$, delay in sanction of loan/ subsidy $(16.67 \%)$, and damage caused by animals/ rodents $(10.00 \%)$. All the problems at overall level are found significant at 5 per cent level except lack of technical knowledge, irregular water supply, clogging of emitters, complicated procedure for loan/subsidy and lack of guidance that means there was no difference in response of each category of farmers to these problems. 


\section{Problems faced by apple cultivators under with drip and without drip irrigation system in the study area}

Table 3: Comparison between problems encountered by with drip and without drip irrigation apple growers (Multiple response, \%)

\begin{tabular}{lccc}
\hline Problems of drip irrigation & $\begin{array}{c}\text { With } \\
\text { Drip }\end{array}$ & $\begin{array}{c}\text { Without } \\
\text { Drip }\end{array}$ & $\begin{array}{c}\text { Chi } \\
\text { square }\end{array}$ \\
\hline High cost of establishment & 53.33 & 86.67 & $7.94^{*}$ \\
Lack of financial support & 23.33 & 60.00 & $16.13^{*}$ \\
Lack of technical knowledge & 53.33 & 70.00 & 2.25 \\
Irregular water supply & 43.33 & 33.33 & 1.30 \\
Irregular electric supply & 63.33 & 36.67 & $7.11^{*}$ \\
High cost of spare parts & 66.67 & 33.33 & $11.11^{*}$ \\
Clogging of emitters & 83.33 & - & - \\
Material transport facilities & 53.33 & 26.67 & $8.89^{*}$ \\
Complicated procedure for & & & \\
loan/subsidy & 46.67 & 53.33 & 0.44 \\
Delay in sanctioning of loan/ & & & \\
subsidy & 60.00 & 16.67 & $24.49^{*}$ \\
Lack of guidance & 46.67 & 60.00 & 1.67 \\
Lack of knowledge on subsidy & 6.67 & 73.33 & $55.56^{*}$ \\
Damage caused by animals/ & & & \\
rodents & 53.33 & 10.00 & $29.65^{*}$ \\
Irregular services & 46.67 & 20.00 & $10.67^{*}$ \\
Difficulty in inter cropping & 66.67 & 33.33 & $11.11^{*}$ \\
Spare parts not available at & & & \\
village & 63.33 & 26.67 & $14.94^{*}$ \\
\hline
\end{tabular}

*Significant at 5 per cent level of significance.

\section{CONCLUSION}

The growth rate in the productivity of apple in the state and its contribution towards expansion of total production has presented a dismal picture which is a cause of concern to the development planners and scientists. In order to improve the productivity levels, serious efforts are needed to rejuvenate the senile and old apple orchards to arrest the decreasing trends in productivity. In Himachal Pradesh since apple cultivation is mostly practiced on rainfed areas, therefore in situ soil conversation practices and watershed management to harvest rain water for prolonged availability needs to be urgently promoted in the apple producing regions. It is therefore, the most important step that the water potential should be exploited to the fullest extent in the study area. The irrigation input not only increases its on productivity but also the productivity of associated inputs. So, Farmers should adopt drip irrigation in their orchards to increase production, productivity and resource use. Drip irrigation has been adopted by farmers but most of the farmers are still not aware of this system. So it should be popularized among the orchardists to enhance the yield, reduce weed population, exercise savings in cost and improve fruit quality. Awareness should be raised among the farmers about the subsidy which is available for the installation of drip irrigation system. Training should be organized at institutional level or field level for efficient use of drip irrigation by farmers. Government should provide low cost emitters, which will help to overcome the problem of clogging of emitters.

The study revealed that majority of the respondents of drip irrigation technology belongs to middle age group. Hence, there is a need to encourage young farmers to adopt this technology. Majority of the respondents were having medium extension contacts. Hence, the extension personnel should have regular contacts with the farmers adopting drip irrigation technology for effective farm advisory service.

\section{REFERENCES}

Anonymous. 2017. National Horticulture Board, New Delhi.

Barse, K.N., Gohad, V.V. and Lunge, M.R. 2010. Adoption of drip irrigation system by orange growers in Amravati taluka. Agriculture Update, 5: 346-348.

Bhuriya, R., Choudhary, S. and Swarnakar, V.K. 2016. Study of problems and prospects of drip irrigation system on chilli crop in Barwani district of M.P. India. Int. J. Sci. Res., 5: 748-750.

Desai, C.P., Patel, A.A. and Patel, M.R. 1999. Constraints faced by mango growers in adoption of drip irrigation system. Gujarat Agricultural Universities Research Journal, 24: 52-57.

Gulkari, K.D., Chauhan, N.B. and Onima, V.T. 2017. Constraints faced by the banana growers in adoption of risk management practices in drip irrigated banana cultivation. Agriculture Update, 12: 84-88.

Ingale, P.V. and Sagane, N.A. 1992. Constraints in the use of drip irrigation system: a case study. Journal of Maharashtra Agricultural Universities, 17: 294-297.

Meti, C.B. 2012. Studies on factors influencing the drip irrigation adoption, constraints and remedial measures to increase area under drip irrigation. Int. J. Agric. Eng., 5: 236-239.

Pandya, P.A. and Dwivedi, D.K. 2016. Constraints in adoption of drip irrigation. Advances in Life Sciences, 5: 2405-2411. 
Parmar, S.D. and Thorat, G.N. 2016. Constraints faced by farmers in drip irrigation system. Agriculture Update, 11: 229-233.

Patil, B.O. and Poddar, R.S. 2016. Financial feasibility of drip irrigation system in grape cultivation. International Journal of Agriculture, Environment and Biotechnology, 9: 617-624.

Singh, P. 2017. Economics of production and marketing of peach in Sirmaur district of Himachal Pradesh. Thesis M Sc(Ag). Dr Y S Parmar University of Horticulture and Forestry, Faculty of Agriculture, Nauni, Solan, India.

Thorat, D.F. and Bhoite, H.S. 1992. The socio economic constraints in the use of drip irrigation. Maharashtra Journal of Extension Education, 11: 324-326.
Uday, R., Bhosale, V. and Bhande, S.R. 2007. Analytical study of drip irrigation system installed for grape orchards. Financial Agriculture, 30: 16-19.

Veverka, V. and Pavlacka, R. 2012. The effect of drip irrigation on the yield and quality of apples. Acta Univ. Agric. Silvic. Mendelianae Brun., 60: 247-252.

Yadav, K., Yadav, J.P. and Kumari, A. 2017. Constraints encountered by farmers in adoption of drip irrigation system in district Jaipur. Journal of Krishi Vigyan, 6: 32-36. 